\title{
The Effect of Research and Development Expenditures on Economic Growth: New Evidences
}

\author{
Asst. Prof. Dr. Mustafa Ildırar (Çukurova University, Turkey) \\ Assoc. Prof. Dr. Mehmet Özmen (Çukurova University, Turkey) \\ Asst. Prof. Dr. Erhan İşcan (Çukurova University, Turkey)
}

\begin{abstract}
Research and Development (R\&D) is one of the most important variables that affect the country's economic growth and development through increasing the technology capabilities, enlargement of resource base and promoting in the capability of resource utilization. Countries that innovate by conducting R\&D activities always have high economic growth and many researchers emphasized this prominent role of the R\&D on economic growth in numerous studies. This study contributes in two ways to this stream of research. Providing new estimates of the effect of R\&D expenditures on economic growth is the first contribution to literature. On the other hand, there are different types of R\&D expenditures and each of them has different magnitude on the economic growth. Therefore, this study provides evidences about the magnitudes of R\&D expenditures. The effect of different types of $R \& D$ expenditures on economic growth for the selected OECD countries is examined in this study by utilizing from GMM framework using the data belonging the period of 2003-2014. Income and different R\&D expenditure data used to analyze that obtained from OECD Stat. As a conclusion, it is found that all of the R\&D expenditures have positive and significant effect on economic growth in selected OECD countries but magnitudes are various. Therefore, policy makers should design the R\&D stimulation policies depending on the characteristics of the countries. Accordingly, countries must allocate more resources to different types R\&D expenditure for achieving sustainable rate of growth.
\end{abstract}

\section{Introduction}

Being an information society in the first quarter of 21 st century in the world maintains its priority. Technological development not only affects the country's economic system but also changes political and social structure of the country. That's why all the countries deal their science and technology politics as a system and get in a big race in order to get the globalized technology. Today's advanced and modern societies are known as "Information Society". Information society expresses a public organization for that all kinds of knowledge are produced, obtained, spread and used easily. It shouldn't be ignored that the truth of being an information society is not easy. In this regard, it is necessary to develop technology. As one of the gaining ways of technology, different factors have to get together in order to develop technology in the country.

Central countries have a high effect on the nearby countries on the field of information and technological level in today's world economies. It is seems that these countries effects are increasing both on political and economic side. Also development in the globalization period formed with the technological development and reflected as the new economic politics.

The most important role in creating the new development process is the technological development. Technological superiority that determines the economic balances creates a rivalry environment among all world countries. Industrial enterprises that symbolize the countries wealthiness, economic power, welfare level are continuing competition of efficiency for directing the future from today. Today, technology is the key of economic rivalry. That is why the countries which do not want to fall behind in competition have to follow an affective technology policy.

Developed and developing countries emphasize improving technology to overcome crisis or to increase the competitiveness. 21st century's essential characteristic for all areas is the continuous change. Between all the varieties of changes so far the most important one is technological change. There are several sources of technological inventions and innovation. Today, the most important source is the work of R\&D units operating in various industries. $R \& D$ refers for activities of corporate or governmental innovation. R\&D is a component of innovation and also an aimless invention effort. Innovation builds on R\&D and commercializing complete the phase. Basic characteristics of $\mathrm{R} \% \mathrm{D}$ are taking long periods with high costs and uncertain results with chance of failure. However, that risk of failure could be reduced to minimum level by organizing R\&D activities very effectively and planned.

\section{Theoretical Framework}

Emphasizing the importance of economic growth is a quite difficult. The fact that income increased more than ten folds in USA and some European countries in the 20th Century is beyond doubt the result of technological progress. Understanding the fact of economic growth has particularly progressed from the 1980s. From the beginning of mid-1980s, the case of economic growth has become one of the most highlighted research subjects 
in the science of economy. In this framework, it is clear that literature has significantly expanded to determine the sources of economic growth or factors affecting this growth. Majority of the studies on growth theory can be divided into three groups (Evenson, 1997, Jones, 2007, Bozkurt, 2015):

First group is the Post-Keynesians growth models that emphasize the incentive role of saving and investment on growth.

Second group is the Neo-Classical growth models that signify the technologic progresses as the locomotive of economic growth.

Third group is the New Growth Theory, also known as the Endogenous Growth Theory, which emphasizes the important effects of the factors behind the technological development such as R\&D, human capital accumulation, and externalities on long term growth, instead of assuming that the growth occurs as a result of the technological developments which are kept out of the model and emerge spontaneously.

The traditional theory of economy claims that the technology moves freely between the countries to a great extent and technological change has a key role in explaining the growth. However, it is known that there are big and continuous differences among the growth rates of countries. The New Growth Theory developed by a group of economists leaded by Romer (1986) and Lucas (1988) by looking at the deficiencies of the traditional economy has not only created a new interest on determinant qualifications of economic growth and technological progress, but also revived the discussions on the optimum role of the State in R\&D activities.

It is observed within the new endogenous theories that the primary drive power to ensure the sustainability of the growth is based on the R\&D sector and models putting importance to support the inputs relevant to R\&D have an important place. Despite the fact that literature includes many studies on the subject, three approaches can be considered to be distinct and other studies are the derivatives which are based on these three. These three models are Paul Romer's model (1990), Grossman and Helpman's model (1991), and Aghion and Howitt's (1992) model. The common characteristics of these three studies should be; R\&D activities, Human capital employed in the R\&D sector, and the growth models based on the R\&D specific new products.

The fact that the economy has not only the level effect but also the continuous growth effect in the long term depends on the number of researchers (science people, engineer, technical personnel) transferred to the sector by the economy. The more economy has such inputs and ensures the development of new products and technologies by means of conveying these resources to the R\&D sector successfully, the more the rate of the economic growth will be higher (Romer 1990, Grossman and Helpman 1991, Aghion and Howitt 1992, Ateş 1998).

In today's literature of economy, it is observed that technology strengthens its place in all production functions as an endogenous but not an external factor for economics. The cost reducing nature of the technology in given capital and labor force conditions through time utility comes first among the most discussed and interested subjects. The studies carried out in this regard also stresses the features of R\&D and the technological change caused by it as following:

i. Technological change is mainly shaped by the R\&D activities of the companies under their own body,

ii. The idea that the small and incremental technological change is the most important determinant of the productivity increases both in company level and macro level started to be accepted by many,

iii. The studies on industrialized countries indicate that these small and incremental technological changes have been performed in the different departments inside the company rather than the regular R\&D departments,

iv. This small and incremental technological change does not only reduce the unit costs, but also has an influence on capacity increase, quality and input increase, and many other variables thereof.

Considering these characteristics of the technological change, the thought that the technology is monopolized by some countries and all innovations can be realized by them should be avoided by developing countries in particular. As clear, the determinant role of technology on economic development and growth process seems to increase more and more nowadays. And even, the role of science and technology in trade and international competition has become so significant that the international economic development classifications are now modified as the countries producing technology and others with no production of technology.

\section{The Importance of R\&D Expenditures and R\&D Expenditures in Some Selected OECD Countries}

R\&D activities on a large scale have reached its scientific content and professional specialization size. Technological innovation in advanced laboratories and pilot founding's to full time employees are emerging as a result of the activities of highly qualified specialists. On the other hand about three activities of R\&D can be mentioned. First is the basic research. They are the studies which are original studies in order to obtain new scientific knowledge and understanding. The applicability of knowledge in basic research and practical value of the research isn't concern of the researches. Second is the applied research that is using information obtained as a result of basic research aimed to find exact or approximate solution to a problem. Third is the development that is 
using scientific knowledge in order to put new substantially improved materials, tools, products and manufacturing processes to the system or the service. In other words the results of basic and applied research activities are related to products or production processes.

Today, R\&D activities have reached a large scale, scientific content and vocational expertise level. Technological innovations have been arisen by high qualified full-time paid experts' works in the developed laboratories and pilot plants. It can be said that R\&D is an indispensable element of today's industrial companies in terms of efficiency and profitability. Thus, today, in both the USA and EU countries, and also in Japan, no matter how big the company is, each of them place big importance on R\&D works so as to create a new product, new production processes or to develop products.

Changes in the age of information have led countries to place more importance on R\&D. Firms, corporations and universities are coming up with new products and solutions by benefiting from staff of $\mathrm{R} \% \mathrm{D}$ and accumulation of knowledge obtained from previous studies. R\&D expenditures are one of the variables commonly used to define the ability of a corporation or a country to use technology. R\&D expenditures are of capital importance in every stage of technological activities such as coming up with a new product, developing production method and using, modifying and altering existing or imported technology effectively. Countries have started to compete with one another about $R \& D$ expenditures. The main reason why countries place such great importance on $R \& D$ expenditures is because the added value and price made by these expenditures are very high. This is shown in Table 1.

\begin{tabular}{|l|l|}
\hline Concrete & 1 cent \\
\hline Cement & 5 cent \\
\hline Iron and Steel & 50 cent \\
\hline Aluminum & 1.5 dollar \\
\hline Automobile & $10-100$ dollar \\
\hline Commercial plane & $100-1.000$ dollar \\
\hline Gunship & $2.000-3.000$ dollar \\
\hline Mobile phone & 4.000 dollar \\
\hline Fighter & 10.000 dollar \\
\hline Satellite & 100.000 dollar \\
\hline Micro and Nano chips & 4.000 .000 dollar \\
\hline
\end{tabular}

Table 1. The Price of 1 Kilo of Product Source: http://www.bursa-smmmo.org.tr/yazarlar/makaleler/132AGE.pdf

Technological composition of the products manufactured is crucial as it allows one to evaluate the competitive powers, production structures of the countries and how much importance they place on R\&D. Concordantly, it is clearly shown in Table 1 how important it is to manufacture products that have high added-value. We can consider the knowledge-based economy is important for producing goods and services that has high added value. One of the most important criteria of producing a product that have high added-value is not to forget to increase $R \& D$ expenditures within gross national product.

R\&D expenditures are accepted as one of the most important indication of countries' creative efforts. In this context, in the years of 2000 and 2013, the proportion of R\&D expenditures as the percentage of gross national product and the amount of average national income per person in some OECD countries are shown in Table 2. Among some chosen countries (29 countries), member of OECD, South Korea is the first by spending approximately $42 \%$ of its GNP on the R\&D works, followed by Israel and Japan, respectively. While average in OECD countries was $2.14 \%$ in 2000 , this rate rose to $2.37 \%$ in 2013 . As there were 22 countries below the average in 2000, that number fell to 17 in 2013. Across the entire OECD area, a majority of countries increased R\&D expenditures in this period. There has also been a significant increase in GDP per capita. 


\begin{tabular}{|c|c|c|c|c|}
\hline \multirow[t]{2}{*}{ Country } & \multicolumn{2}{|c|}{$\begin{array}{l}\text { Gross Domestic Expenditures on R\&D } \\
\text { (as \% of GDP) }\end{array}$} & \multicolumn{2}{|c|}{$\begin{array}{c}\text { Gross Domestic Product (GDP) } \\
\text { US dollars/capita }\end{array}$} \\
\hline & 2000 & 2013 & 2000 & 2013 \\
\hline Austria & 1.89 & 2.96 & 29574 & 45133 \\
\hline Belgium & 1.92 & 2.43 & 28300 & 41595 \\
\hline Canada & 1.87 & 1.69 & 29156 & 43038 \\
\hline Czech Rep. & 1.12 & 1.91 & 16259 & 28963 \\
\hline Denmark & n.a & 3.06 & 29575 & 43797 \\
\hline Estonia & 0.60 & 1.71 & 9680 & 26160 \\
\hline France & 2.08 & 2.24 & 25996 & 37617 \\
\hline Germany & 2.39 & 2.83 & 26645 & 43282 \\
\hline Greece & n.a & 0.81 & 19344 & 25523 \\
\hline Hungary & 0.79 & 1.40 & 12089 & 23507 \\
\hline Ireland & 1.09 & 1.54 & 29627 & 46858 \\
\hline Israel & 3.93 & 4.09 & 24832 & 32713 \\
\hline Italy & 1.01 & 1.31 & 26658 & 34781 \\
\hline Japan & 3.00 & 3.47 & 25941 & 36225 \\
\hline Korea & 2.18 & 4.15 & 18092 & 33089 \\
\hline Luxembourg & 1.57 & 1.30 & 56518 & 93234 \\
\hline Mexico & 0.33 & 0.50 & 9974 & 16891 \\
\hline Netherlands & 1.81 & 1.96 & 31543 & 46749 \\
\hline Norway & n.a & 1.65 & 36799 & 65635 \\
\hline Poland & 0.64 & 0.87 & 10611 & 23616 \\
\hline Portugal & 0.72 & 1.33 & 17852 & 27651 \\
\hline Slovak Rep. & 0.64 & 0.83 & 11137 & 26586 \\
\hline Slovenia & 1.36 & 2.60 & 17878 & 28675 \\
\hline Spain & 0.88 & 1.26 & 21718 & 32549 \\
\hline Sweden & n.a & 3.31 & 29385 & 44586 \\
\hline Turkey & 0.48 & 0.94 & 9177 & 18599 \\
\hline U.K & 1.72 & 1.66 & 27451 & 38743 \\
\hline USA & 2.62 & 2.74 & 36416 & 52592 \\
\hline OECD Total & 2.14 & 2.37 & 25090 & 37815 \\
\hline
\end{tabular}

Table 2. Gross Domestic Expenditures on R\&D (as \% of GDP) and Gross National Product (per capita) in Some Selected OECD Countries Source: OECD

\section{Literature Review}

There are too many scientific studies that investigate whether any factor has a possible influence on economic growth. With the adoption of the fact that technological change is one of the most important factors which will affect economic growth through new growth theories, numerous theoretical and empirical studies analyzing also the effects of R\&D, which is an indispensable component of technological change, on economic growth have taken place in the literature. In this context, while in general the relationship between R\&D expenditures and economic growth is handled in the majority of conducted studies, it is seen that in some studies the relationship between patent and growth and the one between high-tech exports and economic growth have been covered. Except for those, it is also seen that the studies investigating the causal relationship between R\&D and exports have been conducted (Sungur et al, 2016). In empirical studies made on R\&D, the results obtained may be arguable and findings may differ depending upon the distinctions of analysis procedure, analysis period, economic structure in examination and indicators.

Lichtenberg (1993) examined the relationship between the private and public sector R\&D expenditures and economic growth for the period 1964-1989 by incorporating 74 countries into the analysis. In the study, it is concluded that while private sector $R \& D$ expenditures affect growth in a positive way, public sector $R \& D$ expenditures do not create any positive effect on economic growth and even sometimes they have a negative impact on it.

Goel and Ram (1994), in their study covering 52 countries for the period 1960-1980, found that there is a significant relationship between R\&D expenditures and economic growth in the long term; however, the direction of causality between the variables could not be determined.

Park (1995) concluded that local private sector R\&D investments are a significant determinant of the increase in both local and foreign factor productivity with the data of 10 OECD countries in the period of 1970-1987.

Freire - Seren (1999) detected a $1 \%$ increase in total R\&D expenditures increases real gross domestic product (GDP) at a rate of $0.08 \%$; in the case of taking the parameters that define the innovation technology into account 
they concluded that the elasticity of R\&D expenditures is close to one with the data of 21 OECD countries during the period 1965-1990.

Slywester (2001) found that there is no any relationship between R\&D expenditures and growth for the countries in question; when G-7 countries are taken into consideration, the results revealed that there is a positive relationship between especially industrial R\&D expenditures and growth with data of 20 OECD countries.

Ülkü (2004) analyzed the relationship between R\&D, innovation and economic growth by means of various panel data procedures for 30 countries (20 OECD, 10 non-OECD) for the period 1981-1997 and concluded that for both OECD and non-OECD countries under investigation, there is a positive relationship between innovation created by R\&D sector and GDP per capita; however, innovation does not lead to a continuous increase of economic growth.

Yanyun and Mingqian (2004) used Partial Least Square (PLS) regression model by using the data pertaining to some Asian countries and found that R\&D expenditures have a positive impact on economic growth. In a similar manner, Falk (2007) analyzed the long term relationship between R\&D investments and economic growth for the period 1970-2004 and put emphases on that as the share of R\&D investments in GDP becomes larger, GDP per capita also increases.

Wang (2007) expressed that the countries which employ R\&D expenditures effectively will achieve a better economic growth performance with the data of 30 countries. In their study covering USA data, Goel, Pay and Ram (2008) investigated if a relationship exists between federal and non-federal R\&D expenditures and economic growth for the period 1953-2000 and concluded that the relationship between economic growth and federal R\&D expenditures is much stronger than the other. Kue and Yang (2008) made a research upon the effects of the knowledge capital and technological diffusion on regional economic growth for China and emphasized that R\&D capital and technology imports contribute significantly to economic growth.

Samimi and Alerasoul (2009) used panel data method in their research for the period 2000-2006 and 30 developing countries and the findings have shown that because of low R\&D expenditures in these countries, economic growth and R\&D expenditures do not exhibit a mutual causal relationship.

On the other hand, Sandrouil and Zina (2009) conducted a study which covers 23 countries for the period 1992 2004 by applying dynamic panel data method and found that there is a positive and significant relationship between R\&D expenditures and economic growth.

Saraç (2009) revealed that R\&D expenditures affect economic growth in a positive direction for the period 19832004 and 10 OECD countries.

Korkmaz (2010) evaluated the relationship between R\&D expenditures and economic growth for Turkey through Johansen cointegration method for the period 1990-2008. They found that there is a long term relationship between R\&D and economic growth.

Bravo-Ortega and Marin (2011) examined the data of 65 countries for the period 1965-2005. According to the study conducted by panel data procedure, $10 \%$ increase in R\&D expenditure per capita will increase total factor productivity by approximately $1.6 \%$ in the long term.

Eid (2012) found that R\&D expenditures made through higher education effects growth by increasing productivity with the data of 17 high-income OECD countries between period 1981-2006.

Gülmez and Yardımcıoglu (2012) analyzed the relationship between R\&D expenditures and economic growth by using panel causality and cointegration methods for the period 1990-2010 and 21 OECD countries. According to the findings obtained in the study, it has been observed that there is a bidirectional causal relationship between $\mathrm{R} \& \mathrm{D}$ expenditures and economic growth in the long term and $1 \%$ increase in R\&D expenditures will increase economic growth at a rate of $0.77 \%$.

Wang et al. (2013) found that R\&D expenditures for high-tech sectors effects GDP per capita levels with the data of 23 OECD countries for the period 1991-2006. These expenditures have a positive influence on GDP per capita.

Amaghouss and Ibourk (2013) examined the relationship between entrepreneurship, innovation and economic growth through panel data method for OECD countries with the data of 2001-2009 periods. They used the entrepreneurial activities and innovation to measure entrepreneurship and found that entrepreneurial activities and innovation have significant and positive effects on economic growth.

Inekwe (2014) made a classification of 66 countries into different income groups for 2000-2009 periods. Inekwe expressed that impact of R\&D expenditures on economic growth exhibits differences over the short and long term and in countries with upper-middle income level; the impact is much larger and significant when compared to countries with low-income levels. 


\section{Methods and Data}

This research investigates the impact of $R \& D$ expenditures on economic growth. For this purpose, we used dynamic panel data based on the two-step generalized method of moments (GMM) the model. Annual data of 29 selected OECD countries from 2003 until 2014 is used in this study and obtained from OECD statistics. According to theoretical framework, the empirical model is as follows:

$$
\begin{aligned}
& \mathrm{GDP}_{\mathrm{i}, \mathrm{t}}=\alpha_{0}+\beta_{1} \mathrm{GDP}_{\mathrm{i}, \mathrm{t}-1}+\beta_{2} \mathrm{BX}_{\mathrm{i}, \mathrm{t}}+\beta_{2} \mathrm{GX}_{\mathrm{i}, \mathrm{t}}+\varepsilon_{\mathrm{i}, \mathrm{t}} \\
& \text { where }
\end{aligned}
$$

GDP $_{\mathbf{i}, \mathbf{t}} \quad$ : Gross domestic product for country $\mathrm{i}$ in period $\mathrm{t}$

$\mathbf{G D P}_{\mathbf{i}, \mathbf{t}-\mathbf{1}}$ : The lag of dependent variable

$\mathbf{B X}_{\mathbf{i}, \mathbf{t}} \quad$ : Business enterprise expenditure on $R \& D$ for country $i$ in period $t$

$\mathbf{G X}_{\mathbf{i}, \mathbf{t}} \quad$ : Government Intramural Expenditure on R\&D for country $\mathrm{i}$ in period $\mathrm{t}$

$\varepsilon_{\mathrm{i}, \mathrm{t}} \quad:$ Errors terms

All the variables in the model are in logarithmic form. Then, we use two-step the generalized method of moment estimator (GMM) for estimating effect of R\&D expenditures on economic growth. It is based on dynamic panel models and this type of GMM estimator eliminates the problems of serial correlation, heteroscedasticity, and endogeneity of some variables. Specifying the instrumental variables in this approach is especially important. The GMM estimator is consistent only if the lagged values of the explanatory variables are valid instruments. Sargan test is used to examine the overall validity of the instruments. Also we must the specification test to investigate the second-order serial correlation of the residuals in first differences. Besides to confirm convenient model specification, the first-order serial correlation should be confirmed whereas the second-order serial correlation should be rejected (Khordehfrosh and Tehranchian, 2015).

\section{Empirical Results}

As stated in equation (1), we examine the effects of R\&D expenditures on economic growth of selected OECD countries. In this model, business enterprise expenditure and government intramural expenditure are used as independent variables for analysis and Gross Domestic Product as an explanatory variable in the model. The results of the model's estimation using the generalized method of moments are presented in Table 3.

\begin{tabular}{|l|l|}
\hline Variables & Coeff \\
\hline $\mathrm{GDP}_{\mathrm{i}, \mathrm{t}-1}$ & .688765 \\
& $(0.000)^{*}$ \\
\hline $\mathrm{BX}_{\mathrm{i}, \mathrm{t}}$ & .097779 \\
& $(0.000)^{*}$ \\
\hline $\mathrm{GX}_{\mathrm{i}, \mathrm{t}}$ & .0178965 \\
& $(0.000)^{*}$ \\
\hline Wald Test & $\chi^{2}(3)=52611.44$ \\
& {$[0.0000]^{*}$} \\
\hline Sargan Test & $\chi^{2}(54)=28.94915$ \\
& {$[0.9979]$} \\
\hline Specification Tests & -3.055 \\
\hline AR(1) & {$[0.0022]$} \\
\hline AR(2) & -1.604 \\
& {$[0.1087]$} \\
\hline
\end{tabular}

Table 3. The Results of Estimation * represent statistical significance at the $1 \%$.

According to the estimation results, business enterprise expenditure has a positive and statistically significant effect on economic growth. This result implies that if business enterprise expenditure increases one percent, GDP increases about $0.1 \%$. Government intramural expenditure is the second variable that we interpreted. Likewise, Government intramural expenditure has a significant and positive effect on economic growth in our model. This result also implies that if government intramural expenditure increases one percent, GDP increases about $0.02 \%$. All of the results are similar with the literature. The estimated variables are statistically significant and the signs are as expected. We run the entire diagnostic tests for the estimation and found no any problem about the estimation. There is only one issue about the estimation results: magnitude of the coefficients. The coefficients are quite slight but these are not only the determinants of the GDP so this magnitude is also expected. As a result, these estimation results indicate that $R \& D$ expenditures have a significant impact on economic growth in selected OECD countries. 


\section{Conclusion}

Nowadays, R\&D and innovation play an important role for economic development. According to the international statistics, if a country's R\&D intensity is high, in that situation, the national competitiveness of this country would be much higher than in other countries. On the other hand, many scholars have investigated the relationship between $R \& D$ and economic growth. According to the endogenous growth model, the long term economic development could be achieved through gaining productivity. The increase in productivity, it is provided with technological development. Most studies agree that Technological competitiveness of providing high efficiency and innovation lead to acceleration of economic growth rate. Additionally, it is observed that the differences between welfare of the countries are determined according to the knowledge and innovation capacity. To sum up, science and technology affects the countries' economic transformation and sustainable growth. It is concluded that technological development arises from R\&D activities. In this context, countries to achieve sustainable economic growth transfer large amounts of resources to R\&D activities and innovation. Because, technological development, if and only occur with the R\&D activities.

\section{Acknowledgements}

This study was supported by Research Fund of the Cukurova University.

\section{References}

- Aghion, Howitt, 1992. “A model of Growth in through Creative Destruction”, Econometrica, 60 (2) , p.323

- Amaghouss, Ibourk 2013. "Entrepreneurial Activities, Innovation and Economic Growth: The Role of Cyclical Factors Evidence from OECD Countries for the Period 2001-2009”, International Business Research, 6(1), p. 153

- $\quad$ Ateş, 1998. Yeni İçsel Büyüme Teorileri ve Türkiye Ekonomisinin Büyüme Dinamiklerinin Analizi, Doktora Tezi, Çukurova Üniversitesi, Sosyal Bilimler Enstitüsü, Adana,1998

- Bozkurt, 2015. "R\&D Expenditures and Economic Growth Relationship in Turkey", International Journal of Economics and Financial Issues, 5(1), p.188

- Bravo-Ortega, Marin, 2011. “R\&D and Productivity: A Two Way Avenue?”, World Development Vol. 39, No. 7, pp. 1090

- $\quad$ Eid, 2012. "Higher Education R\&D and Productivity Growth: An Emprical Study on High-Income OECD Countries", Education Economics, 20(1), p.53

- Evenson, 1997. "Economic Growth, International Technological Spillovers and Public Policy:Theory and Emprical Evidence from Asia", Yale University Economic Growth Center Discussion Paper No:777

- Falk, 2007. "R\&D spending in the high-tech sector and economic growth", Research in Economics, 61(3), p. 140

- $\quad$ Freire-Seren, 1999. “Aggregate R\&D Expenditure and Endogenous Economic Growth”, WP,436.99

- Goel, Ram, 1994. "Research and Development Expenditures and Economic Growth:A Cross Country Study", Economic Development and Cultural Change, 42(2),p.403

- Goel, Payne, Ram, 2008. "R\&D expenditures and US economic growth: A disaagrgated approach", Journal of Policy Modelling, 30(2),p.237

- Grossman, Helpman, 1991. Innovation and Growth in the Global Economy, The MIT Press, London.

- Gülmez, Yardımcıoğlu, 2012. "OECD Ülkelerinde Ar-Ge Harcamaları ve Ekonomik Büyüme İlişkisi: Panel Eşbütünleşmeve Panel Nedensellik Analizi (1990-2010)”, MaliyeDergisi, 163, p.335

- Inekwe, 2014. "The Countribution of R\&D Expenditures to Economic Growth in Developing Countries", Social Indicators Research, (124), p.1

- Jones, 2007. İktisadi Büyümeye Giriş (2nd ed.). Çev: Sanlı Ateş \& İsmail Tuncer, İstanbul: Literatür Yayıncilik.

- Khordehfrosh, Tehranchian, 2015. "The Impact of Monetary Policies on the Exchange Rate: A GMM Approach", Iranian Economic Review, 19(2), 177-191.

- Korkmaz, 2010. “Türkiye'de AR-GE Yatırımları ve Ekonomik Büyüme Arasındaki İlişkinin Var Modeli İle Analizi”, Journal of Yasar University, 20(5),p.320

- Kuo, Yang, 2008. "Knowledge Capital and Spillover on Regional-Economic Growth: Evidence From China”, China Economic Review, 19(4),p.594.

- Lichtenberg, 1993. "R\&D Investment and International Productivity Differences", NBER Working Papers, Vol.W4161 
- Lucas, 1988. “On the mechanics of Economic Development”, Journal of Monetary Economics. (22), p.3

- Park, 1995. “International Spillovers of R\&D Investment and OECD Economic Growth”, Economic Inquiry 33(4), p. 571

- Romer, 1986. "Increasing returns and long-run growth", Journal of Political Economy, (94), p.71

- Romer ,1990, “Endogenous Technological Change”, Journal of Political Economy, 98 (5), p.71

- Samimi, Alerasoul, 2009. "R\&D and Economic Growth: New Evidence from Some Developing Countries", Australian Journal of Basic and Applied Sciences, 3(4),p.3464

- Sandrouil, Zina, 2009. "A Dynamic Panel Data Analysis for R\&D Cooperation and Economic Growth", International Journal of Foresight and Innovation Policy, 5(4), p.218

- Saraç,2009.“Araştırma-Geliştirme Harcamalarının Ekonomik BüyümeÜzerindekiEtkisi: Panel Veri Analizi”, Econ Anadolu, 2009Anadolu International Conference in Economics, 17-19 Haziran, Eskişehir.

- Slywester, 2001. "R\&D and Economic Growth, Knowledge”, Technology and Policy, 13(4), p.71

- Sungur, Aydın, Eren, 2016. “Türkiye'de Ar-Ge, İnovasyon, İhracat ve Ekonomik Büyüme Arasındaki İlişki:AsimetrikNedensellikAnalizi”,Süleyman Demirel Üniversitesi İktisadi ve İdari Bilimler Fakültesi Dergisi C.21, S.1, p.173

- Ülkü, 2004. "R\&D, Innovation and Economic Growth: An Emprical Analysis", IMF Working Paper, $\mathrm{W} / \mathrm{P} / 04 / 185$

- Wang, 2007. "R\&D efficiency and economic performance: A cross country analysis using the stochastic frontier approach", Journal of Policy Modelling, 30(2), p.237

- Wang, Tiffany, Liu, 2013. "Heterogeneous Effect of High-Tech Industrial R\&D Spending on Economic Growth", Journal of Business Research, 66(10),p.1990

- Yanyun, Mingqian, 2004. "R\& D and Economic Growth: Panel Data Analysis in ASEAN+3 Countries" A Joint Conference of AKES, RCIE and KDI: Korea and the World Economy, III, July 3-4, Sungkyunkwan. 